\title{
Evaluation of the Ionizing Radiations Effects on The Hematological Parameters of Practicing Medical Radiographers in South-East, Nigeria
}

\author{
Efe Omita ${ }^{1}$, Chikwendu Emenike Orji ${ }^{1}$, Kelechukwu B Okeoma ${ }^{1}$, Michael Promise Ogolodom ${ }^{2 *}$, \\ Peter E Ojike ${ }^{1}$, Caleb Ayoade Aborisade ${ }^{3}$, Oji Galadima Onuk ${ }^{4}$ and Awajimijana Nathaniel \\ Mbaba $^{5}$ \\ ${ }^{1}$ Department of Physics, Federal University of Technology, Nigeria
}

${ }^{2}$ Department of Radiography and Radiological Sciences, Nnamdi Azikiwe University, Nigeria

${ }^{3}$ Department of Physics and Engineering Physics, Obafemi Awolowo University and Department of Physical Sciences, First Technical University, Nigeria

${ }^{4}$ Department of Physics, Federal University Gashua, Nigeria

${ }^{5}$ Department of Radiology, Rivers State University Teaching Hospital, Nigeria

*Corresponding author: Michael Promise Ogolodom, Department of Radiography and Radiological Sciences, Nnamdi Azikiwe University, Nnewi Campus, Anambra State, Nigeria.

To Cite This Article: Efe Omita, Chikwendu Emenike Orji, Kelechukwu B. Okeoma, Michael Promise Ogolodom, Peter E Ojike, et al., Evaluation of the Ionizing Radiations Effects on The Hematological Parameters of Practicing Medical Radiographers in South-East, Nigeria. Am J Biomed Sci \& Res. 2021 - 13(5). AJBSR.MS.ID.001906. DOI: 10.34297/AJBSR.2021.13.001906.

Received: 䟧 July 24, 2021; Published: 非 July 28, 2021

\section{Abstract}

Background: Long-term exposure to low doses of ionizing radiation may adversely affect the human cells, especially the peripheral blood cell count. Changes in the hematological parameters of a radiation worker may serve as an indicator of the health effects of ionizing radiation. This study was designed to evaluate the effects of ionizing radiation on the hematological parameters of practicing medical radiographers in Southeast, Nigeria to help in the early diagnosis of radiation-related damage.

Materials and Methods: This was a cross-sectional experimental study carried out among 30 healthy practicing medical radiographers that were occupationally exposed to low doses of ionizing radiation in the radiology departments of three government hospitals in Southeast, Nigeria and 32 non-radiation workers as controls. Nine hematological-hemoglobin, red blood cell, white blood cells, Platelets, Hematocrit (HCT), Mean Corpuscular Volume (MCV), Mean Corpuscular Hemoglobin (MCH), Mean Corpuscular Hemoglobin Concentration and Lymphocytes measured by BC 5150 Auto Hematology Analyzer and the correlation between years of experience and changes in hematological parameters of radiographers were tested using linear regression analysis test.

Results: Out of 30 Radiographers, 22 (66.67\%) were males while females accounted for 8 (33.33\%). Most 10(33.3\%) of the practicing radiographers were within the age group 36- 40 years with $<10$ years of working experience. The hematological parameters were slightly significantly dependent on radiation exposure status (Wiki's Lambda $=0.732, \mathrm{~F}=2.220 . \mathrm{df}=9$ and $\mathrm{p}=0.05$ ). The results of the simple linear regression of some of the hematological parameters and the radiation exposure status revealed White Blood Cells (WBC) $\left(r^{2}=0.009, p=0.474\right), M C H\left(r^{2}=0.093, p=0.016\right)$ and Lymphocytes $\left(\mathrm{r}^{2}=0.049, \mathrm{p}=0.085\right)$. Conclusion: The values of Red Blood Cells $(\mathrm{RBC}), \mathrm{WBC}$, and Platelets were significantly lower in radiation-exposed workers (Practicing Radiographers) compared to the control while Mean Corpuscular Hemoglobin, mean corpuscular volume, Hemoglobin (Hb), hematocrit, and lymphocytes values were essentially higher among radiographers when compared to the control group. There was no statistically significant relationship between the hematological parameters and the years of exposure of the radiographers.

Keywords: Hematological Parameters; Ionizing Radiation; Medical Radiographers; Lymphocytes; Red Blood Cells; Electromagnetic; Energy; Human Cells; Cytotoxic; Diagnosis; Diabetes Mellitus; Cardiopulmonary Disease 


\section{Introduction}

Radiation in the form of electromagnetic radiation refers to energy transferred from one place to another and maybe ionizing or non-ionizing depending on the amount of energy it possesses. $\mathrm{X}$-ray is a form of ionizing radiation that is found useful in medical imaging. Radiation is harmful in any doses as exposure to radiation at doses used in medical imaging has been linked to the development of cancers [1-4]. Medical imaging modalities that make use of ionizing radiations constitute two-third of radiological procedures [5]. Radiographers as radiation workers are exposed to low doses of ionizing radiation during radiological procedures. Ionizing radiation can induce various forms of cell damage, including the possibility of increasing the incidence of chromosomal aberration. Cytotoxic effects of low dose ionizing radiation in occupationally exposed radiation workers were recorded in several earlier studies [6]. Analyses of hematological parameters such as blood cell count are often employed in routine medical checks. Hematopoietic cells are highly sensitive to ionizing radiation and long-term exposure to low doses of ionizing radiation may adversely affect the human cells, especially the peripheral blood cell count.

Changes in the hematological parameters of a radiation worker may serve as an indicator of the health effects of ionizing radiation. Many research works have been conducted on the effect of ionizing radiation on hematological indices of a radiation worker but only a few were conducted in Nigeria. In a study conducted in southsouth, Nigerian [7] found a low count of White Blood Cells (WBC), Neutrophils, and Lymphocytes, and a higher range of abnormal blood cell morphologies. In an Indonesian study [8] reported higher red blood cell and monocyte counts in radiation-exposed workers [9] in a Palestinian study observed low and high disturbance in the mean values of hematocrit and corpuscular hemoglobin in some medical radiographers. Changes in the hematological parameters of radiation workers can be used to predict radiation damage. This study aimed to evaluate the effects of ionizing radiations on the hematological parameters of medical radiographers in Southeast, Nigeria to help in the early diagnosis of radiation damage.

\section{Materials and Method}

This was a cross-sectional experimental study carried out among 30 apparently healthy radiographers that were occupationally exposed to low doses of ionizing radiation in the radiology departments of three government hospitals in Southeast, Nigeria. Ethical approval (FMC/ASB/A81 VOL.XII/94) for this study was obtained from the Human Research and Ethics Committee Federal Medical Centre Asaba, Delta State, Nigeria. Written informed consent was also obtained from each participant. The control group consisted of 32 apparently healthy subjects chosen from non-radiation workers in each radiology unit of the various hospitals. The control group members were staff in the hospitals that were not exposed to radiation or work with devices that expose them to ionizing radiation. The subject gave their informed consent following an adequate explanation of the aim and experimental details of the study.

All subjects completed a questionnaire, which captured information on socio-demographic variables such as age, gender, and years of employment. Subjects with gross anemia, known history of diabetes mellitus, cardiopulmonary disease, acute or chronic infection, autoimmune disease, and malignancy were excluded. Three milliliters of blood samples were collected from each participant by venipuncture in a disposable syringe and the blood was transferred into a tube containing an anticoagulant (EDTA) in a concentration of $1.5 \mathrm{mg} / \mathrm{ml}$ and then inverted slowly to prevent blood clots. The preparation of blood film slides and staining were carried out at the laboratory according to the standard procedure described by Lewis [10]. The blood count was done on an Auto Hematology Analyzer. The differential count in the radiographers was quantified by an Auto hematology analyzer and was matched with the normal control group. A high-power magnification ( $x$ 400) light microscope was used to view the cell morphology of the entire blood film slides.

The hematological parameters measured in this study include hemoglobin (Hb in $\mathrm{g} / \mathrm{dL}$ ), red blood cell (RBC in count x 1012/L), white blood cells (WBC in count x 109/ l), Platelets (x 109/L), Hematocrit (HCT \%), Mean Corpuscular Volume (MCV fL), Mean Corpuscular Hemoglobin (MCH g), Mean Corpuscular Hemoglobin Concentration (MCHC g/dL) and Lymphocytes (\%). The obtained data were analyzed statistically with a Statistical Package for Social Sciences (SPSS) version 21 (SPSS Inc. Ill USA, 2003). The normality test for the data distribution was done using Mann-Whitney U. An independent-samples t-test was performed on the mean values of the hematological variables to determine the parameters that show a significant difference between the experimental group and the control. A regression analysis was done to evaluate the relationship between the hematological parameters and duration of exposure. The level of statistical significance was set at $\mathrm{p}<0.05$.

\section{Results}

Out of 30 Radiographers that constituted the experimental group, males were $66.67 \%(n=20)$ while females accounted for $33.33 \%(n=10)$. Most 10 (33.3\%) of the participants in the experimental group were within the age group 36-40 years with $<10$ years of working experience (Table 1 ). The results of the mean comparison of some of hematological parameters of the Radiographers (R) Non Radiation (NRW) were (R: $R B C=4.48 \pm 0.645$, NRW: $R B C=465 \pm 1.131, p=0.474), W B C$ (R: 5.96 \pm 2.101 NRW: $6.06 \pm 2.24, p=0.858$ ), HCT (R: $38: 26 \pm 6.653$, NRW: $35.65 \pm 4.72$, 
$\mathrm{p}=0.079)$, PLT (R:190.70 \pm 49.142 , NRW: $218.00 \pm 59.361, \mathrm{p}=0.054)$, Lymphocytes (R: 44.43 \pm 8.586 NRW: $40.28 \pm 9.965$ p=0.085) (Table $2)$. The hematological parameters were slightly significantly dependent on radiation exposure status (Wiki's Lambda $=0.732$, $F=2.220 . d f=9$ and $p=0.05$ ) (Table 3 ). The results of the simple linear regression of some of the hematological parameters and the radiation exposure status revealed $\mathrm{WBC}\left(\mathrm{r}^{2}=0.009, \mathrm{p}=0.474\right)$,
$\mathrm{MCH}\left(\mathrm{r}^{2}=0.093, \mathrm{p}=0.016\right)$ and Lymphocytes $\left(\mathrm{r}^{2}=0.049, \mathrm{p}=0.085\right)$ (Table 4). Table 5 shows the correlation and relationship analysis between the years of exposure and the hematological parameters, and the results revealed that there were no statistically significant relationships between the hematological values and years of exposure to radiation $\mathrm{RBC}(\mathrm{p}=0.901)$ with the model equation $\mathrm{y}=4.444+0.013 \mathrm{x}$, and WBC $(\mathrm{p}=0.241)$ with the model equation of $y=4.963+0.408 x$ (Table 5).

\begin{tabular}{|c|c|c|c|}
\hline Table 1: Distribution of Participants Exposed to Radiation by Demographics. \\
\hline Variable & Category & Number & Percentage (\%) \\
\hline \multirow{3}{*}{ Gender N=30 } & Female & 10 & 33.3 \\
\cline { 2 - 4 } & Male & 20 & 66.7 \\
\cline { 2 - 4 } Age/Experience N=30 & $31-35$ yrs $(<10)$ & 7 & 23.3 \\
\cline { 2 - 4 } & $36-40 y r s(<10)$ & 10 & 33.3 \\
\cline { 2 - 4 } & $36-40 y r s(<10)$ & 7 & 23.3 \\
\cline { 2 - 4 } & $36-40 y r s(<10)$ & 5 & 16.7 \\
\hline
\end{tabular}

\begin{tabular}{|c|c|c|c|c|c|c|}
\hline $\begin{array}{c}\text { Haematological } \\
\text { Parameters }\end{array}$ & Category & Mean \pm SD & t-test & Df & p-value & Remark \\
\hline WBC & $\begin{array}{c}\text { Radiographers } \mathrm{N}=30 \\
\text { Non-Radiation Workers } \mathrm{N}=32\end{array}$ & $\begin{array}{l}5.96 \pm 2.101 \\
6.06 \pm 2.242\end{array}$ & -0.18 & 60 & 0.858 & NS \\
\hline $\mathrm{RBC}$ & $\begin{array}{c}\text { Radiographers } \mathrm{N}=30 \\
\text { Non-Radiation Workers N=32 }\end{array}$ & $\begin{array}{r}4.48 \pm .645 \\
4.65 \pm 1.131\end{array}$ & -0.721 & 60 & 0.474 & NS \\
\hline PLT & $\begin{array}{c}\text { Radiographers } \mathrm{N}=30 \\
\text { Non-Radiation Workers } \mathrm{N}=32\end{array}$ & $\begin{array}{l}190.70 \pm 49.142 \\
218.00 \pm 59.361\end{array}$ & -1.965 & 60 & 0.054 & NS \\
\hline $\mathrm{Hb}$ & $\begin{array}{c}\text { Radiographers } \mathrm{N}=30 \\
\text { Non-Radiation Workers } \mathrm{N}=32\end{array}$ & $\begin{array}{l}12.34 \pm 1.918 \\
11.84 \pm 1.720\end{array}$ & 1.081 & 60 & 0.284 & NS \\
\hline HCT & $\begin{array}{c}\text { Radiographers } \mathrm{N}=30 \\
\text { Non-Radiation Workers } \mathrm{N}=32\end{array}$ & $\begin{array}{l}38.26 \pm 6.653 \\
35.65 \pm 4.723\end{array}$ & 1.79 & 60 & 0.079 & NS \\
\hline MCV & $\begin{array}{c}\text { Radiographers } \mathrm{N}=30 \\
\text { Non-Radiation Workers } \mathrm{N}=32\end{array}$ & $\begin{array}{l}84.26 \pm 6.088 \\
80.58 \pm 8.448\end{array}$ & 1.958 & 60 & 0.055 & NS \\
\hline $\mathrm{MCH}$ & $\begin{array}{c}\text { Radiographers } \mathrm{N}=30 \\
\text { Non-Radiation Workers } \mathrm{N}=32\end{array}$ & $\begin{array}{l}28.67 \pm 2.005 \\
27.10 \pm 2.844\end{array}$ & 2.486 & 60 & 0.016 & Sig \\
\hline $\mathrm{MCHC}$ & $\begin{array}{c}\text { Radiographers } \mathrm{N}=30 \\
\text { Non-Radiation Workers } \mathrm{N}=32\end{array}$ & $\begin{array}{c}33.52 \pm .932 \\
33.53 \pm 1.727\end{array}$ & -0.041 & 60 & 0.967 & NS \\
\hline Lymphocytes & $\begin{array}{c}\text { Radiographers } \mathrm{N}=30 \\
\text { Non-Radiation Workers } \mathrm{N}=32\end{array}$ & $\begin{array}{l}44.43 \pm 8.586 \\
40.28 \pm 9.965\end{array}$ & 1.752 & 60 & 0.085 & NS \\
\hline
\end{tabular}

Table 3: Multivariate Analysis of Haematological Parameters by Radiation Exposure Status.

\begin{tabular}{|c|c|c|c|c|c|c|c|}
\hline \multicolumn{2}{|c|}{ Effect } & \multirow{2}{*}{$\begin{array}{l}\text { Value } \\
0.999\end{array}$} & \multirow{2}{*}{$\begin{array}{c}\text { F } \\
8260.575\end{array}$} & \multirow{2}{*}{$\begin{array}{c}\text { Hypothesis } \\
\text { df }\end{array}$} & \multirow{2}{*}{$\begin{array}{c}\text { Error df } \\
52\end{array}$} & \multirow{2}{*}{$\frac{\text { p-value }}{0}$} & \multirow{2}{*}{$\begin{array}{c}\begin{array}{c}\text { Partial Eta } \\
\text { Squared }\end{array} \\
0.999\end{array}$} \\
\hline \multirow{4}{*}{ Intercept } & Pillai's Trace & & & & & & \\
\hline & Wilks' Lambda & 0.001 & 8260.575 & 9 & 52 & 0 & 0.999 \\
\hline & Hotelling's Trace & 1429.715 & 8260.575 & 9 & 52 & 0 & 0.999 \\
\hline & Roy's Largest Root & 1429.715 & 8260.575 & 9 & 52 & 0 & 0.999 \\
\hline
\end{tabular}




\begin{tabular}{|c|c|c|c|c|c|c|c|}
\hline & Pillai's Trace & 0.268 & 2.11 & 9 & 52 & 0.045 & 0.268 \\
\cline { 2 - 8 } Radiation Exposure Status & Wilks' Lambda & 0.732 & 2.11 & 9 & 52 & 0.045 & 0.268 \\
\cline { 2 - 9 } & Hotelling's Trace & 0.365 & 2.11 & 9 & 52 & 0.045 & 0.268 \\
\cline { 2 - 9 } & Roy's Largest Root & 0.365 & 2.11 & 9 & 52 & 0.045 & 0.268 \\
\hline
\end{tabular}

Table 4: Simple Linear Regression of Haematological Parameters by Radiation Exposure Status.

\begin{tabular}{|c|c|c|c|c|c|c|c|c|}
\hline & \multicolumn{4}{|c|}{ Haematological Parameters } & \multicolumn{4}{c|}{ Change Statistics } \\
\hline WBC & $\mathbf{R}$ & $\mathbf{R}^{2}$ & Adjusted $\mathbf{R}^{2}$ & $\begin{array}{c}\text { Std. Error of } \\
\text { the Estimate }\end{array}$ & $\mathbf{R}^{2}$ Change & F & df & p-value \\
\hline RBC & 0.023 & 0.001 & -0.016 & 2.175 & 0.001 & 0.032 & 61 & 0.858 \\
\hline PLT & 0.093 & 0.009 & -0.008 & 0.929 & 0.009 & 0.52 & 61 & 0.474 \\
\hline Hb & 0.246 & 0.06 & 0.045 & 54.661 & 0.06 & 3.862 & 60,1 & 0.054 \\
\hline HCT & 0.225 & 0.051 & 0.035 & 5.737 & 0.051 & 3.204 & 60,1 & 0.079 \\
\hline MCV & 0.245 & 0.06 & 0.044 & 7.402 & 0.06 & 3.832 & 60,1 & 0.055 \\
\hline MCH & 0.306 & 0.093 & 0.078 & 2.474 & 0.093 & 6.182 & 60,1 & 0.016 \\
\hline MCHC & 0.005 & 0 & -0.017 & 1.401 & 0 & 0.002 & 60,1 & 0.967 \\
\hline Lymphocytes & 0.221 & 0.049 & 0.033 & 9.324 & 0.049 & 3.071 & 60,1 & 0.085 \\
\hline
\end{tabular}

Table 5: Regression Equation of Haematological Parameters by Age/Years of Exposure to Radiation.

\begin{tabular}{|c|c|c|c|c|}
\hline \multicolumn{2}{|c|}{ Standardized Beta } & p-value & Regression Equation & Implication \\
\hline WBC & 0.221 & 0.241 & $4.963+0.408 x$ & NS \\
\hline RBC & 0.024 & 0.901 & $4.444+0.013 x$ & NS \\
\hline PLT & 0.154 & 0.417 & $174.492+6.661 x$ & NS \\
\hline Hb & -0.022 & 0.906 & $12.432+(-0.038) x$ & NS \\
\hline HCT & 0.139 & 0.463 & $36.273+0.815 x$ & NS \\
\hline MCV & -0.178 & 0.346 & $28.490+(-0.956) x$ & NS \\
\hline MCH & 0.061 & 0.748 & $33.655+(-.057)$ & NS \\
\hline MCHC & -0.069 & 0.717 & $43.641+0.326 x$ & NS \\
\hline Lymphocytes & 0.043 & 0.821 & NS \\
\hline
\end{tabular}

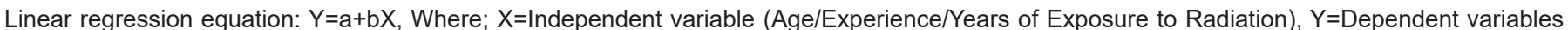
(Haematological Parameters), a=Intercept/constant, b=Slope/regression coefficient (Unstandardized beta), B=Standardized regression coefficient beta. Thus, Haematological Parameters=Constant+Slope/regression coefficient (Unstandardized beta).

\section{Discussion}

Long-term exposure to low doses of ionizing radiation has been reported to have adverse effects on the human cells especially that of the radiation workers [9]. These effects may result in various hematological disorders. In this study, RBC count was lower among Radiographers. This finding agreed with the finding of the study conducted [11], which reported a change in the RBC. This finding is inconsistent with the findings of the studies conducted $[12,13,19]$ which reported that there was no difference in the RBC counts among radiation workers and the control group. The differences in our findings could be attributed to the different sample sizes studied in our various studies. We found lower WBC counts among radiographers than the non-radiation workers. This finding is in keeping with the findings of the studies carried out $[14,15]$ which equally reported lower WBC values among radiation workers. Our finding slightly differs from the results of the studies conducted $[9,12,16]$ which reported that there was no change in the WBC counts among radiation and non-radiation workers.

The discrepancy in our findings could be ascribed to the different sample sizes studied in our studies. The platelet count in this study was lower among the radiographers than the nonradiation workers. This finding agrees with the findings of the studies conducted [13-15,17] which also reported lower values of platelet counts among radiation workers than that of the nonradiation workers. This finding is not in agreement with the results of the studies carried [12,9] which reported no difference in the platelet values among both radiation and non-radiation workers. The differences in our findings could be attributed to the different 
sample sizes studied as well as the geographical variations of the different studies. The Hb, HCT, MCV, MCH, and lymphocytes values were higher among radiographers than non-radiation workers in this study. In [17] study, they reported similar findings with lymphocytes counts $[12,16]$ also reported a higher value of $\mathrm{MCH}$ among radiation workers.

This finding is inconsistent with the findings of the studies conducted $[6,14,16,17]$ which reported lower values of MCH, MCV, HCT and lymphocytes among radiation workers. The difference in our results could be attributed to the small sample size employed in this study when compared to that used by other authors. There was no statistically significant relationship between the hematological parameters and the years of exposure of the radiographers. This implies that the effects of radiation on Radiographers' hematological parameters occur independently of the years of their radiation exposure. This finding agrees with the findings of the studies conducted by $[9,12,18-20]$ which also reported no correlation between the duration of work and hematological parameters.

\section{Conclusion}

The values of $\mathrm{RBC}, \mathrm{WBC}$, and Platelets were significantly lower in radiation-exposed workers (Practicing Radiographers) compared to the control while MCH, MCV, Hb, HCT and lymphocytes values were essentially higher among radiographers compared to the controls. There was no statistically significant relationship between the hematological parameters and the years of exposure of the radiographers.

\section{Conflict of interest}

None exist among authors.

\section{References}

1. Smith-Bindman R, Lipson J, Marcus R, Kwang-Pyo Kim, Mahadevappa Mahesh, et al. (2009) Radiation dose associated with common computed tomography examinations and the associated lifetime attributable risk of cancer. Arch Intern Med 169(22): 2078-2086.

2. Nwodo VK, Chiaghanam NO, Ogolodom MP (2020) Assessment of knowledge and awareness of radiation hazards and protection among patient's relative in South-east, Nigeria. Journal of Clinical \& Diagnostic Research 14(8): 10-13.

3. Aborisade CA (2021) Radiological Implications of Radiation Dose Distribution in Paediatric Patients Undergoing Diagnostic X-Ray Examination in Some Nigerian Teaching Hospitals. International Journal of Engineering Research \& Technology 10(2).

4. Aborisade CA, Famurewa OC, Ibitoye FI, Balogun FA (2019) Organ Dose Distribution and Estimated Cancer Risk to Paediatric Patients Undergoing Computed Tomography in a Nigerian Tertiary Hospital. Journal of Advances in Medicine and Medical Research 29(7): 1-9.
5. Roobottom CA, Mitchell G, Morgan-Hughes G (2010) Radiationreduction strategies in cardiac computed tomographic angiography. Clin Radiol 65(11): 859-867.

6. Zakeri F, Hirobe T, Noghabi KA (2010) Biological effects of low-dose ionizing radiation exposure on interventional cardiologist. Occup Med 60(6): 464-469.

7. Wejie-Okachi C, Agi C, Douglas K (2019) Profile of haematological parameters among radiographers exposed to low-dose X-rays in selected Port Harcourt Healthcare facilities. Asian Journal of Biotechnology and Bioresource Technology 5(1): 1-14

8. Surniyantoro HN, Rahardjo T, Lusiyanti Y, Rahajeng N, Sadewa A, et al. (2019) Assessment of ionizing radiation effects on the hematological parameters of radiation-exposed workers. Atom Indonesia 45(2): 123129.

9. Alnahhal M, Alajeramy Y, Mostapha SA, Khalid Abu S, Sadi Jaber, et al. (2017) Assessment of hematological parameters among medical radiographers at government hospitals, Gaza Strip. American Journal of Medicine and Medical Sciences 7(6): 238-241.

10. Lewis SM, Bain BJ, Bates I (2006) Blood cell morphology in health and disease. Churchill living stone. Elsevier 10.

11. Taqi AH, Faraj KA, Zayna SA, Jalil Said, Ahmed Hameed, et al. (2019) Effects of high doses of X-Ray on hematological parameters and morphology of red blood cells in human blood. Iranian Journal of Medical Physics 16(1): 112-119.

12. Shafiee M, Hoseinnezhad E, Vafapour H, Sajad Borzoueisileh, Md Ghorbani, et al. (2016) Hematological findings in medical professionals involved at intraoperative fluoroscopy. Global Journal Health Science $8(12)$.

13. Meo SA (2004) Hematological findings in male x-ray technicians. Saudi Med J 25: 852-856.

14. Dimitrovski D, Gordana S, Imran M (2018) Haematological profile of healthy workers exposed to low dose radiation. Journal of Natural Scinces Research 8(16).

15. Davoudi M, Keikhaei B, Tahmasebi M (2012) Hematological profile change in radiation field workers. Apadana Journal of Clinical Research.

16. Joudoh HJ, Al-Kaysi AM, Kadhim NF (2018) Effects of external radiation exposure on some hematological parameters of hospitals worker's staff. Biol Appl Environ Res 2(2): 171-179.

17. Shahid S, Mahmood N, Chaudhry MN, Shaharyar Sheikh, Nauman Ahmed, et al. (2014) Assessment of impacts of hematological parameters of chronic ionizing radiation exposed workers in hospitals. Fuuast Journal of Biology 4(2): 135-146.

18. Izadi-Moud A, Izanloo A, Vojdanparast M, Ghazaleh Niknam Shirvan, Ali Eshraghi, et al. (2019) Investigating the Effect of Ionizing Radiation on Hematological Parameters of Catheterization Laboratory Technicians: Multilayer Perceptron Modeling. Annals of Medical Health Sciences Research 9: 684-687.

19. Oskouii MR, Refahi S, Pourissa M, Yaser Tabarraei (2013) Assessment of humoral immunity in workers occupationally exposed to low levels of ionizing radiation. Life Science Journal 10: 5(s).

20. Khorrami, MB, Riahi-Zanjani B (2015) Hematological profile of healthy workers exposed to low dose radiation. Pharmacologuonline. 2: 138141. 